\title{
An Analysis of the Necessity and Opportunity for Creating a Common Regional Geographical Information System on Water Resources in Romania and Bulgaria
}

\author{
Morosanu Gabriela Adina $^{1, *}$, Aniss Moumen², Mohamed Ben-Daoud ${ }^{3}$ \\ ${ }^{1}$ Faculty of Geography, University of Bucharest, Romania \\ ${ }^{2}$ Faculty of Sciences, Ibn Tofail University, Morocco \\ ${ }^{3}$ Faculty of Sciences, Moulay Ismail University, Morocco
}

Copyright (C) 2015 by authors, all rights reserved. Authors agree that this article remains permanently open access under the terms of the Creative Commons Attribution License 4.0 International License

\begin{abstract}
This study aims to examine the accessibility and performance of Romania and Bulgaria in the context of the European Water Directive and their location on the Black Sea coast. To meet this main goal, the analysis was conceived from the standpoint of the existence, implementation and utility of water information systems in these two neighboring countries. Therefore, we took into consideration the projects which have been done so far in the field of the water information systems in Romania and Bulgaria, but we also highlighted the differences between these two states from the point of view of the complexity, and efficiency of their regional unification. To facilitate the study, we focused on the most important projects governed by the European legislation in the hydrological field. These European or national projects aimed at improving the management of information, alert and conservation of water resources in the hydrological and hydrogeological common space of these two countries have been comparatively analyzed. Finally, some perspectives are proposed for a better design of the hydrological projects which main purpose should be the protection and higher - quality research of the water resources in Romania's and Bulgaria's hydrological border area.
\end{abstract}

Keywords Romania, Bulgaria, Water Directive, Danube River, Water Information System, Institutional Twinning

\section{Introduction}

Romania and Bulgaria are located in Southern Europe (Figure 1), and, after January $1^{\text {st }} 2007$, they have become the European Union's pillars in the lower basin of the Danube and in the Black Sea Region.
In addition to the fact that Romania and Bulgaria are neighboring countries, sharing a common border, mostly along the Danube, and that after the fall of communism, they have experienced a similar path of economic development, another significant aspect, from a hydrological point of view, is the presence of the Black Sea, with a 244 kilometer long coastline in Romania and a 378 kilometer long coastline in Bulgaria.

Because the Danube and the Black Sea are key elements of every program and environmental policy initiative originating from both the EU and national water-management institutions, these bodies of water require a complex analysis of the opportunities and current achievements of the joint management of the Romanian and Bulgarian water information systems [3][4][8].

After being admitted in the European Union in 2007, Romania and Bulgaria have acquired full rights with regards to information systems for managing natural resources, particularly water resources [6][10]. The shared watercourse of the Danube, forming the border between these two countries, with all the implications brought about by its water catchment area in their territories (the tributaries that are to be found in the area between the Carpathian and the Balkan Mountains) raise the issue of a common and convergent interest of both Romania and Bulgaria in the field of water management. In addition to the abovementioned elements, there is also the Black Sea Basin, located in the East, which directly receives both the Danube's waters and also those of coastal area rivers [1][7].

Considering these aspects, both of institutional and geographical nature, it becomes evident that this study will prove useful in future enterprises of the two countries to strengthen their cooperation on projects of mutual interest for the management and knowledge of hydrological resources and phenomena occurring in this border space. 


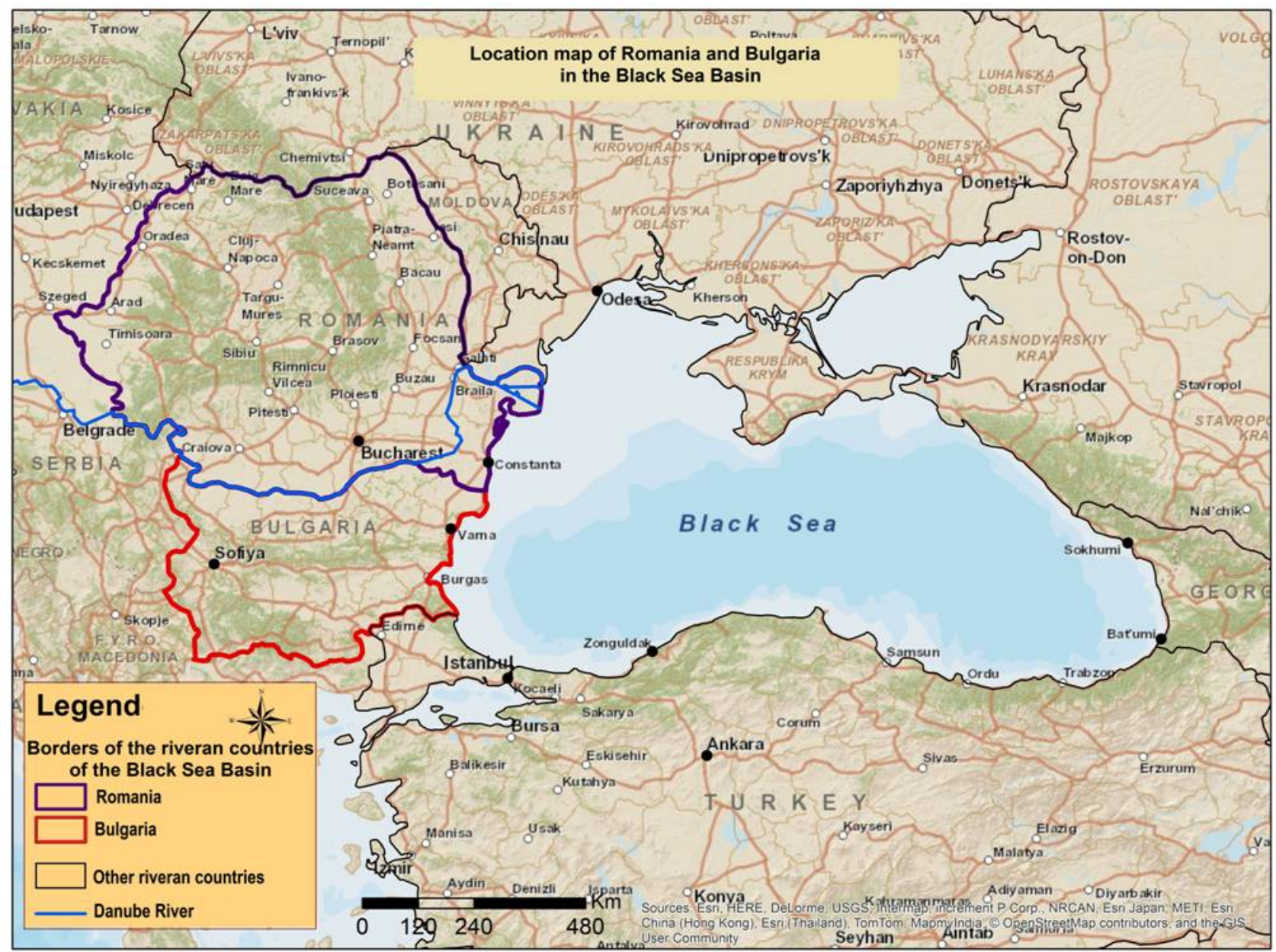

Figure 1. Map of the studied area within the Danube River and the Black Sea

\section{Data and Methods}

For our study, we have utilized bibliographic and information and on-line resources, along with water-related legislation and technical instruments for processing the hydrological data.

Firstly, our research began by studying national and international water-related legislative documents. Subsequently, all the geo-informational data that we found (both shapefiles and raster) were integrated in the evaluation of initiatives and programs that have been created so far in the common Romanian-Bulgarian hydrographical area. Thus, the use of services and spatial data sets was based on the spatial data of the Web-GIS environment. In order to implement the methods for spatial analysis and representation, we used desktop or on-line based mapping tools and software, such as Quantum GIS 2.0, ArcGIS 10.0, and the SmartCover on-line platform [12].

Finally, we used the comparative and analytical methods in order to formulate a critical opinion on the measures that could be taken in order to achieve a better management of GIS water information in Romania and Bulgaria [7][8].

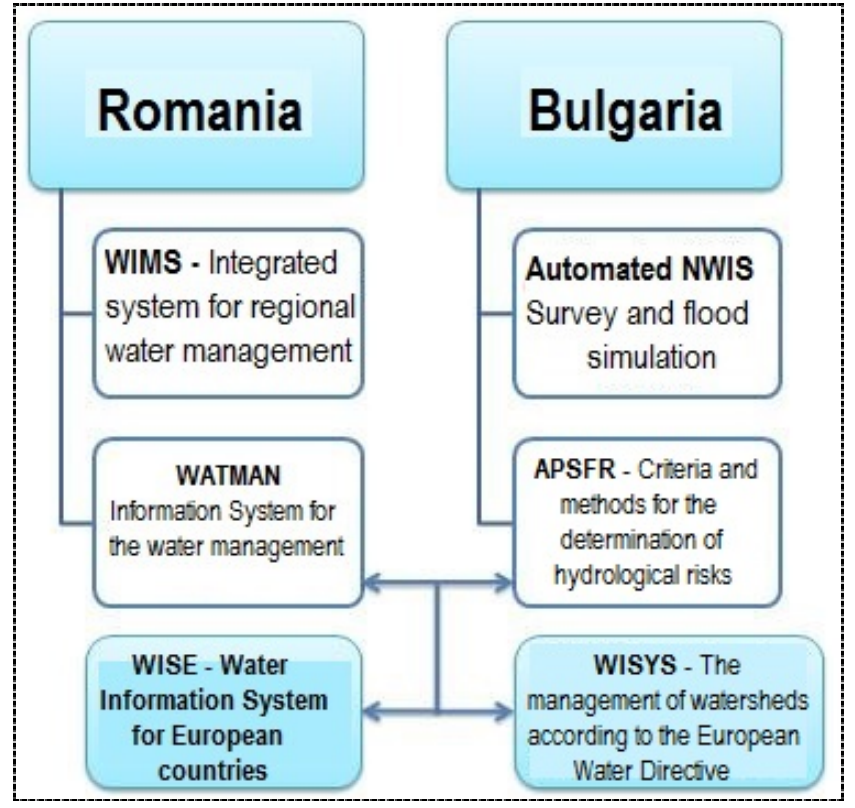

Figure 2. Diagram depicting the main projects in the field of water information systems in Romania and Bulgaria 


\section{Results}

Before EU accession (2007), Romania and Bulgaria had already shown signs that the direction settled by the EU Directive CE 602006 was properly understood at an institutional and decisional level. In this context, notable efforts were undertaken to implement laws and water management plans that were common throughout the new EU member states, such as in the case of our two neighboring countries. Therefore, Romania and Bulgaria, countries rich in terms of hydrology, but with limited perspectives in the SNIE field, received institutional support through a number of technological and methodological projects and programs (Figure 2) [2][3][9].

A good example is the Bulgarian project on the two southernmost sub-basins of the Danube in Bulgaria (the Osam and Vit sub-basins) [1]. At the same time, in Romania, numerous studies of hydrographic basins were undertaken in order to preserve and capitalize on the water's potential in the Buzău River sub-basins located in the Curvature Carpathian area.

In terms of institutional twinning and hydrological research in Romania and Bulgaria, it is necessary to highlight the cooperation program between the Dobrogea Littoral Water Management Department (in Romania) and the National Institute for Hydrology and Water Management of Bulgaria [4][9]. Their activities encompass monitoring the quality of aquatic environments and the management of water information systems for the underground water reserves of the Dobrogea Region, both in Romania and in Bulgaria. At the moment, the program focuses on underground waters, and the spatial data is integrated in the GIS domain through the Feflow hydrological modeling software (Finite Element subsurface FLOW system) [4].

Depending on the source of various data sets used, we could form a critical view on the existence, needs and potential water information systems. This allowed us to create a GIS database for the common Romano-Bulgarian hydrographic area (Figure 3), analogous to the ones created by the SmartCover project. The data that we introduced in the cartographic evidence consisted of polygon and line shapefiles representing the administrative units situated along the Danube, lakes and rivers with permanent flow, and also the altitudinal model for Europe [11], with a resolution of 1 arc, cropped for the studied area.

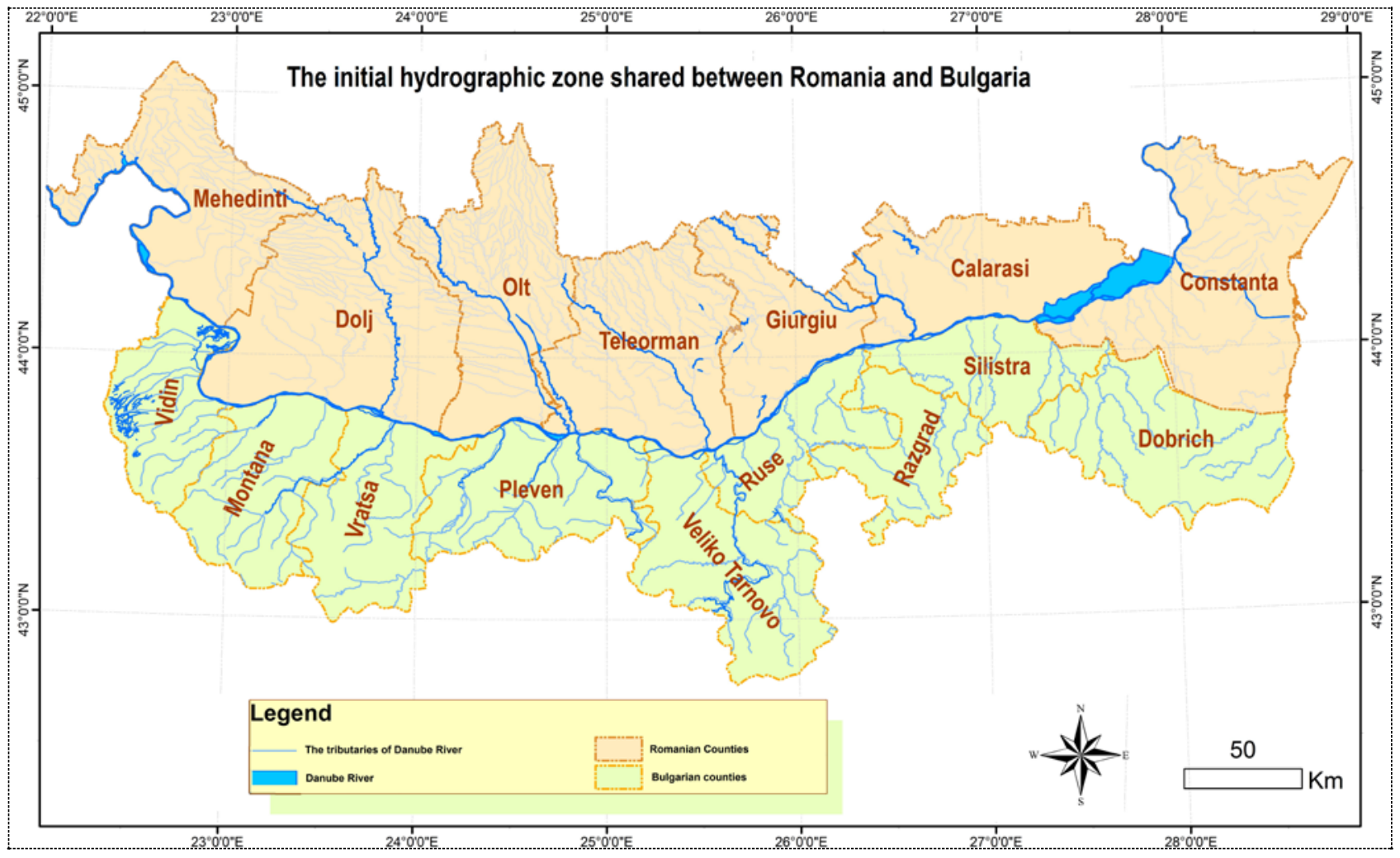

Figure 3. A redrawing of the common Romano-Bulgarian hydrographical area according to the SmartCover project 


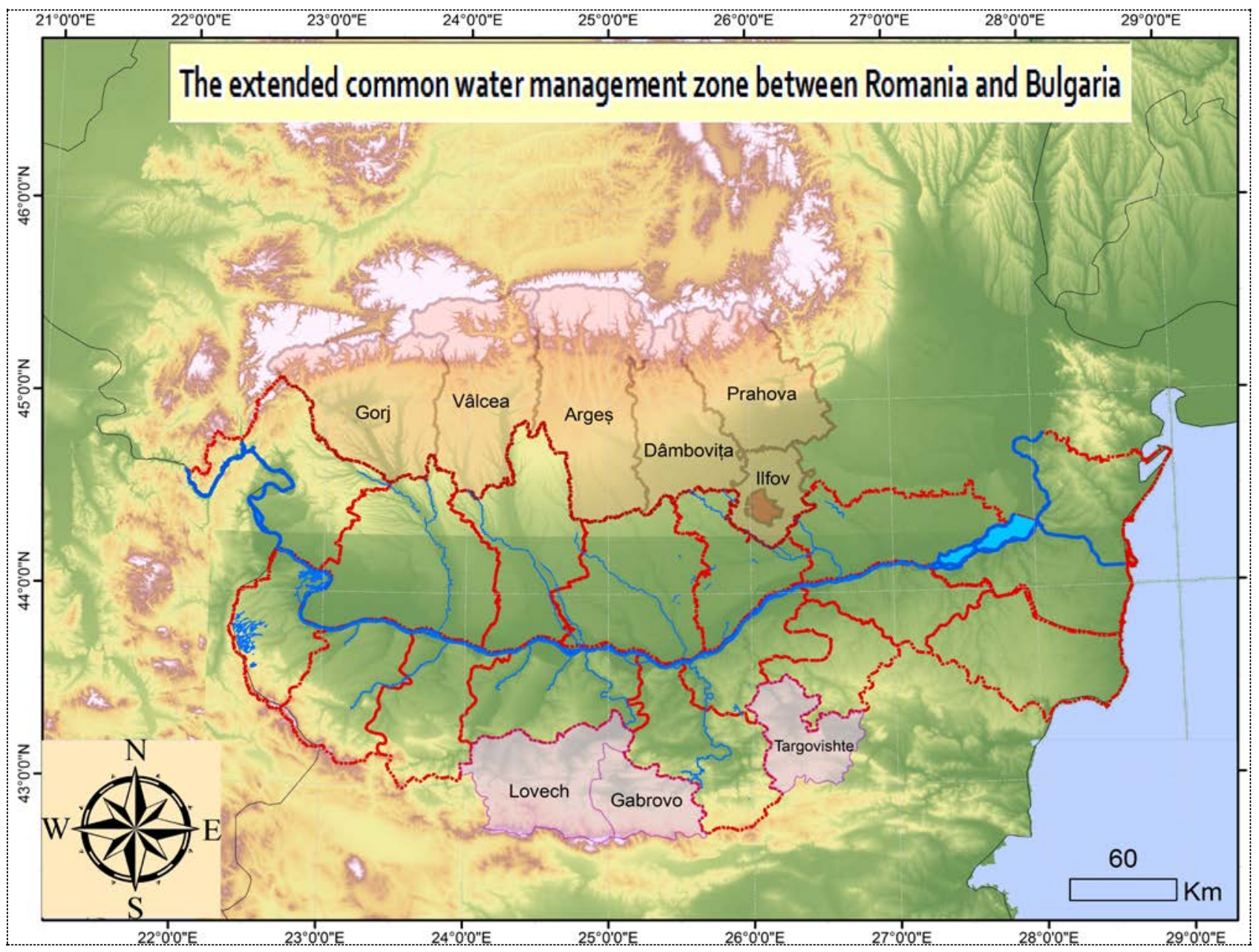

Figure 4. Our proposal for expanding the shared management of rivers, in accordance with the hydrological basins between the Carpathians and Balkan Mountains (6 new counties in Romania and 3 more in Bulgaria)

After verifying the results, we noted that the common Romano-Bulgarian hydrological management area is quite vast, covering 9 Bulgarian and 8 Romanian administrative units. In this region, nine main rivers are to be found (including the Danube) and there are also around 900 secondary river sectors, representing $2^{\text {nd }}$ to $5^{\text {th }}$ degree tributaries of the Danube. Among these watercourses, the largest and most important are the hydrographic basins of Jiu, Olt, Prahova and Ialomița (for the Romanian territory) and Iskar, Iantra and Osam for Bulgaria. On the other hand, Bulgarian rivers are shorter but more uniformly distributed, because they are flowing into a plateau with less morphometric and climatic differences from the area immediately south of the Balkan Mountains, than in Romania. In Figure 4, it is possible to see that the topographic zone covered by the common water management area needs to be enlarged, in order to include the hydrographic basins with their middle (Getic piedmont and Pre-Balkans Plateau) and upper sectors (which coincide with the summits of the Carpathian and Balkan Mountains). Yet, the Romanian and Bulgarian Dobrogea Region along the Black Sea Coast is comprehensive in terms of hydrological interferences and common watershed management.

Because the already established common Bulgarian area crosses, for the most of its part, the northern slopes of the Balkan Mountains, only three administrative units have been added (Lovech, Gabrovo and Târgoviste) in Bulgaria, whereas in Romania, due to a longer distance to the summits of the Carpathian Mountains (known as the line of separation between two basins or distinct hydrographic areas), it was necessary to add six more counties (Gorj, Vâlcea, Arges, Dâmbovita, Ilfov and Prahova). In total, the common hydrographic area of Romania and Bulgaria can hypothetically increase by $34 \%$.

\section{Discussion}

We have noticed the stakes behind previously mentioned integrated water management projects, both for hydrological sciences and for the population benefiting from such projects offering access to good quality water resources. The surface watercourses in the Dobrogea region are quite rare and experience a prolonged dry season (Pontic/Black Sea type hydro-climatic regime, influenced by the conditions found in 
the semi-arid areas between the Black Sea and the Aral Lake), which generates difficulties in ensuring the necessary supply of water. Hence, a joint surveillance system operated by Romania and Bulgaria is the only way of monitoring the underground water table, which supplies most of the necessary water for the population and its economic activities (largely agricultural) in the region.

After seeing the actual projects developed in the hydrological field, where Romania and Bulgaria take part, the most appropriate way to end this study was by employing a SWOT analysis (Table 1).

Based on our analysis, we may assume that the institutional relationships between Romania and Bulgaria will evolve at an accelerated pace, after the beginning of a number of geo-informational projects with multiple perspectives. On the one hand, there are projects focused solely on hydrological issues, such as WIMS and WISE, and on the other, there are more complex projects, which target common hydrological problems that need to be solved by both countries, (SmartCover).

Even though Romania and Bulgaria do not possess all the necessary means to manage on their own a hydrological and informational partnership involving both private (GIS companies) and public partners (research institutes, faculties and ministries), we appreciate the overall efforts towards integration in the area of implementing EU-imposed water legislation.

\section{Conclusions}

This preliminary study has explored the potential joint Romanian-Bulgarian Basin area, in terms of developing or strengthening the future hydrological projects. The information presented by this study highlights the main features of the hydrological interdependence zone between Romania and Bulgaria. In many ways, this region, bordered by the Carpathians, the Balkan Mountains and the Black Sea, is affected by issues concerning the correct and common management of water resources and also issues related to the available technical means for fighting against extreme hydro-meteorological phenomena, all presenting their unique challenges.

We have demonstrated that, as far as the hydrological informational systems are concerned, Romania and Bulgaria's accession to the European Union brought about the adoption of the EU acquis, the harmonization of border management and the progressive elimination of borders for the flow of water-related geo-spatial information. Still in their initial stages, joint Romanian - Bulgarian hydrological programs (such as SmartCover) and related sciences should create a more favorable environment for the hydrological management of shared river basins between these two countries in the common Danube and Black Sea region.

For instance, one shared interest for a more intense collaboration on some common hydrological projects should come from their position along the lower Danube River. This idea is also confirmed by one of the conclusions resulting from our SWOT analysis, which refers to the fact that both the regions of Romania and Bulgaria which surround the Danube's lower course belong to areas that have experienced periods of drought and significant losses of agricultural resources (including changes in plant and soil use and, more importantly for us, water resources).

Table 1. SWOT analysis of the Romano-Bulgarian water informational system

\begin{tabular}{|c|c|}
\hline Strengths & Weaknesses \\
\hline $\begin{array}{l}\text { - The existence of the shared Danube system between } \\
\text { the two countries } \\
\text { - A relatively equal length of coastline and similar } \\
\text { morphological and climatic conditions } \\
\text { - The simultaneous admission in the EU, which } \\
\text { requires a simultaneous creation of adjustment and } \\
\text { improvement programs in both national and regional } \\
\text { water information systems }\end{array}$ & $\begin{array}{l}\text { - A weak level of consultation between environmental ministries and water } \\
\text { management agencies in the two countries and low levels of hydrological research } \\
\text { - The evolution of national projects for the protection of aquatic environments and the } \\
\text { creation of warning systems for water-related risks has not always been the same } \\
\text { - Bulgaria's difficult adaptation to the new hydrological networks imposed by } \\
\text { Europe's water information systems } \\
\text { - The existence of different administrative structures in the two countries, which } \\
\text { affects the homogenization and circulation of hydrological data between various } \\
\text { institutions } \\
\text { - A lack of institutional communication and various ways of working with data bases } \\
\text { and water programs. }\end{array}$ \\
\hline Thre & Opportunities \\
\hline $\begin{array}{l}\text { - The risk of diverging directions of evolution in the } \\
\text { field of water information systems due to different } \\
\text { national political systems and economical } \\
\text { necessities. } \\
\text { - Different rates of absorption and implementations of } \\
\text { EU water-related legislation } \\
\text { - The diverse heritage of both countries' hydrological } \\
\text { information systems. }\end{array}$ & $\begin{array}{l}\text { - The possibility of energy production and hydrological data sharing on the common } \\
\text { Danube border. } \\
\text { - The sharing of surface and underground water resources, which involves the need to } \\
\text { create common data bases for an efficient collaborative effort in the entire lower basin } \\
\text { of the Danube. } \\
\text { - The possibility of regional twinning of hydrological research activities in the area } \\
\text { between the Carpathians and the Balkans, and also the opportunity to reinforce the } \\
\text { statute and goals of environmental organizations working for the protection of the } \\
\text { Black Sea. } \\
\text { - The development of the SmartCover project and platform. }\end{array}$ \\
\hline
\end{tabular}


Afterwards, we have observed and compared the two countries in terms of existing projects and legislative measures taken in the water domain. Even though implementing periods, technical means and project goals differ from one country to another, the rhythm of evolution represents a unifying element, which must remain the same, particularly with regards to the rate of fund absorption in the research, innovation and EU legislation fields. Therefore, there are shared opinions, among which there are the ones pointing out that Romania and Bulgaria should profit from this institutional and geo-spatial twinning opportunity offered by their shared Danube area and improve their hydrological sectors.

On the basis of all these findings, we can conclude that the Romano - Bulgarian hydrological area along Danube River and the Black Sea coast presents the geographical and legislative premises for a common hydrological project, if not at the institutional level, at least at the users' shared hydrological database level.

\section{REFERENCES}

[1] Angelova, G. et al., 2007, Implementation of the EU Water Framework Directive in Bulgaria, Sofia.

[2] Metelka, T., Pryl, K., Suchanek, M., 2010, The Use of Hydro-Information Technology in Central and Eastern Europe Over the Last Decade. In Novatech2010, France.

[3] Morosanu, G.A., Ben-Daoud, M., Moumen, A., Oulidi, H., J., Bouabid, El-M., Essahlaoui, A., Eljaafari, S., 2015, Water
Information Systems in the South-Western Region of the Black Sea, in International Journal of Innovation and Applied Studies, Vol. 10, No. 4 Mar. 2015, pp. 1350-1360.

[4] Pratt, A., Lønholdt, J., Jørgensen, P.E., Persson, B., Nikolov, V., Ianev., R., Dontchev, V., Klint, M., 2005, Implementing the water framework directive in Bulgaria: Integrated river basin management on the Black Sea coast, In Water SciTechnol. 51(11), pp. 53-61.

[5] EUROWATERNET and Waterbase, European Environmental Agency. Available at: http://edz.bib.uni-mannheim.de/daten/edz-bn/eua/04/Eurowa ternet_final_low_res.pdf

[6] The official website of the Romanian Water Administration Agency "Apele Române" - www.rowater.ro

[7] The EU Commission environmental website/water section water.europa.eu

[8] The European website for national data on waterfloods.jrc.ec.europa.eu/national-water-level-information. html

[9] European Water Information System: http://water.europa.eu

[10] Implementing the Water Directive in Bulgaria. Available at: http://www.gwp.org/en/ToolBox/CASE-STUDIES/Europe/ Bulgaria-Implementation-of-EU-Water-Framework-Directiv e-286/

[11] http://www.diva-gis.org/gdata

[12] http://cbc171.asde-bg.org/index_en.php

[13] http://www.fao.org/nr/water/aquastat/data/query/index.html? lang=en

[14] http://www.statsilk.com/maps/useful-free-gis-shapefile-maptools 